\title{
Nitro Compounds in Introduced Astragalus Species
}

\author{
M.C. WILLIAMS AND A.M. DAVIS
}

\begin{abstract}
Leaves of foreign Astragalus species were examined for the presence and type of poisonous aliphatic nitro compounds. Twenty-two (24\%) of the 92 species examined tested positive for nitro compounds and $70(76 \%)$ tested negative. Three nitrobearing species, Astragalus bodeanus Fisch., Astragalus isfahanicus Boiss., and Astragalus siliquosus Boiss. synthesized 3-nitro-1-propanol (3-NPOH). The other nitro-bearing species synthesized 3-nitropropionic acid (3-NPA). Ten taxonomic sections had a high percentage of nitro-bearing species. Chemotaxonomic relationships in Astragalus suggest that most, if not all, of the other species in these 10 sections would synthesize nitro compounds.
\end{abstract}

Many Astragalus species foreign to the United States, particularly those from Europe and Asia, are suitable for introduction for use as forage and ornamentals, or for reclamation in the United States. Some species could be used to revegetate areas of the western United States depleted by overgrazing or disturbed by strip mining and other causes incident to the exploration for new sources of energy. Because about $67 \%$ of the land in the 11 western contiguous states is rangeland, these species would likely be extensively used as forage by both livestock and wildlife. Introduced Astragalus must, therefore, be examined for toxicological properties to insure that no harmful species are released.

More than half of the 558 species and varieties of North American Astragalus synthesize toxic aliphatic nitro compounds, and another $5 \%$ accumulate toxic levels of selenium from the soil or synthesize unidentified toxic compounds associated with locoism (Williams and Barneby 1977a). Presumably, a sizable number of the approximately 1,500 Old World and South American species would also be poisonous and could become troublesome pests if introduced on western ranges and pastures.

Interception of the poisonous Astragalus before their release would prevent future livestock losses, range deterioration, time and expense of developing unsuitable species, and ultimately, costly eradication programs. Over 35 purposefully introduced species have become costly weed problems in the United States (Williams 1980). More than half of these are poisonous.

The most common poisons found in Astragalus in North America are the nitro compounds (Williams and Barneby 1977a). These compounds are subdivided into those that are catabolized in the digestive tract of ruminants to 3-nitro-1-propanol (3-NPOH) or 3-nitropropionic acid (3-NPA) (Williams and James 1975). The former is more toxic to ruminants because it is more rapidly absorbed from the digestive tract.

Old World and South American Astragalus leaflets sampled from herbarium specimens were analyzed qualitatively for nitro compounds. Nitro compounds in Astragalus are relatively stable and they have been detected in leaves from herbarium specimens

\footnotetext{
Authors are plant physiologist, Poisonous Plant Research Laboratory, Agricultural Research Service, Science and Education Administration, U.S. Department of Agriculture, Logan, Utah 84321; and agronomist, Western Regional Plant Introduction Station, Agricultural Research Service, Science and Education Administration,

U.S. Department of Agriculture, Pullman, Washington 99163.

Manuscript received Apri] [8, 1980.
}

over 100 years old. About $7 \%$ of the species examined were positive for nitro compounds (Williams and Barneby 1977b). Astragalus species were often chemotaxonomically related so that the nitrobearing species were grouped in taxonomic sections or subgenera.

Germplasm of over 150 Astragalus species has been brought into the United States and grown at the Western Regional Plant Introduction Station. Some of these species are the subject of active research, while others have already been released for seeding as named cultivars. To prevent the accidental release of poisonous Astragalus, we examined many of these species for the presence and type of nitro compounds.

\section{Materials and Methods}

The Poisonous Plant Research Laboratory received 114 specimens or accessions of Old World Astragalus from the U.S.D.A., Western Regional Plant Introduction Station, Pullman, Washington. Sixty-eight were received as seed and 46 as dried plants from collections made in the station nursery. Eight species were received as seed from the U.S.D.A. Soil Conservation Service (SCS) Plant Materials Center at Aberdeen, Idaho. Samples of two species were collected from plots at the Agronomy Farm, Logan, Utah.

Ninety-two species of Old World Astragalus were present in the 124 accessions. Sixty-two were identified as to species; 30 were identified only by a plant introduction number. The 30 unnamed species were assumed here to be different species, although possible duplication may be found upon identification.

Fifty seeds of each species were scarified and planted in $15.2-\mathrm{cm}$ pots in the greenhouse. As soon as sufficient foliage was available to produce $25 \mathrm{~g}$ of dry weight, the aerial parts were harvested and dried at $60^{\circ} \mathrm{C}$. Dried plant material from each accession was combined and ground to pass a $16-\mathrm{mesh} / \mathrm{cm}$ screen before analysis. The concentration of nitro compounds is highest when plants are in vegetative to pre-bloom growth. The concentration of nitro compounds in Astragalus declines after seed is formed.

All accessions of Astragalus were analyzed quantitatively for nitro compounds by the method of Cooke (1955) as modified by Williams and Norris (1969). In a few instances when germination was poor or when plants failed to develop under greenhouse conditions, plants were assayed qualitatively by the method previously described (Williams and Barneby 1977a).

The type of nitro compound (3-NPOH or 3-NPA) was determined by thin-layer chromatography. Approximately $0.5 \mathrm{~g}$ of dried plant was extracted for $24 \mathrm{hr}$ at room temperature in $50 \mathrm{ml}$ of $80 \%$ ethanol and filtered to remove solid material. The filtrate was extracted twice with 50-ml aliquots of benzene. The ethanol extract was evaporated to dryness on a rotary evaporator, and the residue was redissolved in $2 \mathrm{ml}$ of $95 \%$ ethanol. The ethanol solution was hydrolyzed with $8 \mathrm{ml}$ of $3 \mathrm{~N} \mathrm{HCl}$ on a steam bath for $3 \mathrm{hr}$, by which time the total solution was reduced to $1 \mathrm{ml}$. The extract was chromatographed on silica gel plates in 5:3 benzene:methanol. The nitro compounds were visualized with a diazotized $p$-nitroaniline spray of Majak and Bose (1974). The Rf values of the spots were compared with those of authentic samples of 3-NPOH and 3-NPA.

\section{Results and Discussion}

Twenty-two of the 92 species examined (24\%) tested positive for 


\begin{tabular}{|c|c|c|c|c|}
\hline Identification number & Species & Origin & $\begin{array}{c}\text { Nitro analysis } \\
\text { (mg NO} / \mathrm{g} \text { of plant) }\end{array}$ & Type of nitro compound \\
\hline D 2012 & A. alopecias Pall. & U.S.S.R. & 5.9 & No spot \\
\hline PI 220158 & A. bakaliensis Bge. & Afghanistan & 8.0 & 3-NPA \\
\hline PI 380748 & A. bodeanus Fisch. & Iran & 6.6 & 3-NPOH \\
\hline P1 289649 & A. bourgaeanus Coss. & Spain & 11.2 & 3-NPA \\
\hline PI 318944 & A. cymbicarpos Brot. & Spain & 6.4 & 3-NPA \\
\hline PI 244273 & A. edulis Coss. \& Durieu & Spain & -1 & - \\
\hline Pl 66440 & A. falcatus Lam. & U.S.S.R. & 56.4 & 3-NPA \\
\hline PI 220769 & A. filicaulis F. \& M. & Afghanistan & 6.7 & 3-NPA \\
\hline PI 383593 & A. glycyphyllos L. & Turkey & 5.2 & 3-NPA \\
\hline PI 307949 & A. hamosus L. & Algeria & 11.5 & 3-NPA \\
\hline PI 227444 & A. isfahanicus Boiss. & Iran & 10.5 & 3-NPOH \\
\hline D 2140 & A. macropterus DC. & U.S.S.R. & 84.8 & 3-NPA \\
\hline PI 223335 & A. odoratus Lam. & Iran & 50.8 & 3-NPA \\
\hline PI 314223 & A. peduncularis Royle & U.S.S.R. & 28.7 & 3-NPA \\
\hline PI 214099 & A. refractus C.A.M. & Spain & 9.6 & 3-NPA \\
\hline PI 330696 & A. siliquosus Boiss. & Iran & 9.1 & 3-NPOH \\
\hline PI 241587 & A. sinicus $\mathrm{L}$. & Taiwan & -1 & - \\
\hline PI 221431 & A. tephrosioides Boiss. & Afghanistan & 5.6 & No spot \\
\hline PI 214102 & A. trimestris L. & Spain & 9.4 & 3-NPA \\
\hline PI 420694 & Species & U.S.S.R. & 14.1 & 3-NPA \\
\hline PI 420686 & Species & U.S.S.R. & 11.0 & 3-NPA \\
\hline PI 420693 & Species & U.S.S.R. & 9.9 & 3-NPA \\
\hline
\end{tabular}

Insufficient material for quantitative analysis. Qualitative analysis indicated a concentration of 4 to $8 \mathrm{mg}$ of $\mathrm{NO}_{2} / \mathrm{g}$ of plant.

nitro compounds (Table 1 ) and 70 species (76\%) tested negative. All accessions of an individual species were either positive or negative for nitro compounds. Astragalus bodeanus Fisch., Astragalus isfahanicus Boiss., and Astragalus siliquosus Boiss. synthesized 3-NPOH at 6.6 to $10.5 \mathrm{mg} \mathrm{NO} / \mathrm{g}$. Both $A$. isfahanicus and $A$. siliquosus are in section Theiochrus. Astragalus bodeanus is in section Megalocystis.

Emory milkvetch (Astragalus emoryanus var. emoryanus (Rydb.) Cory), a native of Texas and New Mexico, synthesizes 5 to
$9 \mathrm{mg}$ of $\mathrm{NO}_{2} / \mathrm{g}$ of plant as 3-NPOH. During an unusually heavy infestation of this plant in 1975, mortality of cattle and sheep on range near Roswell, New Mexico, was between 2 to 3\% with morbidity 15 to $20 \%$ (Williams et al. 1979). All known foreign 3-NPOH-bearing Astragalus would also be highly toxic to ruminants.

Several Old World sections of Astragalus that include 3 to 15 species each have a high percentage of nitro-bearing species (Table 2). Chemotaxonomic characteristics of the nitro-bearing Astraga-

Table 2. Taxonomic sections of Astragalus that contain significant percentages of nitro-bearing species.

\begin{tabular}{|c|c|c|c|c|}
\hline Astragalus section & $\begin{array}{l}\text { No. of species } \\
\text { world wide }{ }^{1} \\
\pm\end{array}$ & $\begin{array}{c}\text { No. of species } \\
\text { examined }\end{array}$ & $\begin{array}{c}\text { No. of nitro-bearing } \\
\text { species }\end{array}$ & Nitro-bearing species \\
\hline Brachycarpus Boriss. & 8 & 2 & 2 & $\begin{array}{l}\text { A. densiflorus Kar. \& } \mathrm{Kir} \text {. } \\
\text { A. heterodontus Boriss. }\end{array}$ \\
\hline Buceras Bge. & 8 & 3 & 3 & $\begin{array}{l}\text { A. bubaloceras Maire } \\
\text { A. hamosus L. } \\
\text { A. trimestris } \mathrm{L} \text {. }\end{array}$ \\
\hline Hemiphaca Kar. \& Kir. & 15 & 3 & 2 & $\begin{array}{l}\text { A. macropterus } \mathrm{DC} \text {. } \\
\text { A. williamsii } \mathrm{Rydb} .^{2}\end{array}$ \\
\hline Hemiphragmium Bge. & 10 & 10 & 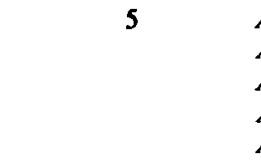 & $\begin{array}{l}\text { A. aboriginum Richards. }{ }^{2} \\
\text { A. australis (L.) Bge. } \\
\text { A. cottoni } \text { M.E. Jones }{ }^{2} \\
\text { A. himalayanus Klotzsch } \\
\text { A. polycladus Bur. \& Franch. }\end{array}$ \\
\hline Melanocercis Bge. & 7 & 4 & 3 & $\begin{array}{l}\text { A. hermoneus Boiss. } \\
\text { A. massiliensis Lam. } \\
\text { A. sirinicus Ten. }\end{array}$ \\
\hline $\begin{array}{l}\text { Melilotopsis Gontsch. } \\
\text { Oroboidei A. Gray }\end{array}$ & $\begin{array}{l}3 \\
6\end{array}$ & $\begin{array}{l}1 \\
4\end{array}$ & $\begin{array}{l}1 \\
4\end{array}$ & $\begin{array}{l}\text { A. melilotoides Pall. } \\
\text { A. eucosmus B.L. Robins. }{ }^{2} \\
\text { A. oroboides Hornem. } \\
\text { A. politowii Krylov } \\
\text { A. robbinsii (Oakes) A. Gray }{ }^{2}\end{array}$ \\
\hline $\begin{array}{l}\text { Severzowia Bge. } \\
\text { Theiochrus Bge. }\end{array}$ & $\begin{array}{l}3 \\
6\end{array}$ & $\begin{array}{l}2 \\
2\end{array}$ & $\begin{array}{l}1 \\
2\end{array}$ & $\begin{array}{l}\text { A. compositus Pavlov } \\
\text { A. isfahanicus Boiss. } \\
\text { A. siliquosus Boiss. }\end{array}$ \\
\hline Uliginosi A. Gray & 9 & 6 & 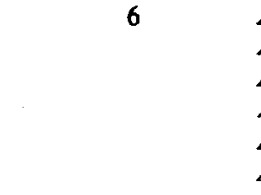 & $\begin{array}{l}\text { A. canadensis } \mathrm{L} .{ }^{2} \\
\text { A. falcatus Lam. } \\
\text { A. odoratus Lam. } \\
\text { A. oreganus Nutt. ex T. \& G.2 } \\
\text { A. peduncularis Royle } \\
\text { A. uliginosus L. }\end{array}$ \\
\hline
\end{tabular}


lus suggest that most, if not all, of the other species in these sections synthesize nitro compounds. Some of these species have been identified as nitro-bearing through analysis of leaflets from herbarium specimens (Williams and Barneby 1977a; Williams and Barneby 1977b). Four sections, Hemiphaca, Hemiphragmium, Oroboidei, and Uliginosi, have nitro-bearing species in both Asia and North America.

All species examined in section Uliginosi (Old World = section Eudomus), Astragalus falcatus Lam. (sicklepod milkvetch), Astragalus odoratus Lam., and Astragalus peduncularis Royle, synthesized 3-NPA compounds. Three other species from this section, Astragalus canadensis L., Astragalus oreganus Nutt. ex T. \& G., both from North America (Williams and Barneby 1977a) and Astragalus uliginosus L. from China, are also nitro-bearing (Williams and Barneby 1977b). Sicklepod milkvetch was introduced into the United States about 1920 and has been studied extensively (but not toxicologically) for over 50 years. The plant was recommended for range seeding. The discovery of high levels of 3-NPA (up to $84 \mathrm{mg} \mathrm{NO} / \mathrm{g}$ ) in sicklepod milkvetch foliage and its toxicity to livestock has resulted in the recommendation that the species not be seeded and that existing stands be eradicated (Williams et al. 1976).

Astragalus hamosus L. of section Buceras is of interest because it is being considered for introduction into Australia (Desborough 1976). Australia has no indigenous Astragalus. The two species now found there, Astragalus hamosus L. and Astragalus sesameus L., were inadvertently introduced. Astragalus hamosus appears to be excellent sheep forage and grows well on Australian range. A cultivar of $A$. hamosus, Ioman, derived from germplasm introduced from Israel, has been registered with the New South Wales Department of Agriculture (anonymous 1977). Four accessions of A. hamosus (seed from Spain, Iran, Turkey and Algeria) grown in Logan, Utah, synthesized 9 to $11 \mathrm{mg} \mathrm{NO} / \mathrm{g}$ as 3-NPA in leaves. Leaf samples of $A$. hamosus sent from Australia assayed $10 \mathrm{mg}$ $\mathrm{NO}_{2} / \mathrm{g}$ (Williams 1980). Two other members of this 8-member section Astragalus bubaloceras Maire (Williams and Barneby 1977b) and Astragalus trimestris L., are known to synthesize nitro compounds.

The nitro content of $A$. hamosus is so low that the plant would be only marginally toxic to livestock under range conditions. No problems have been encountered in Australia to date; however, the effects on livestock that graze Astragalus with low levels of 3-NPA over long periods are unknown.

Several conclusions may be drawn concerning the potential use of foreign nitro-bearing Astragalus as forage in the United States. First, no species should be released that synthesizes miserotoxin or any other compound that catabolizes to $3-\mathrm{NPOH}$ in ruminants. Such speices would be unsuitable for utilization in any capacity, even as ornamentals, because of the danger that they might escape and become a poisonous weed in pastures and ranges. This group of Astragalus would include $A$. bodeanus, $A$. isfahanicus, and $A$. siliquosus and possibly all other species in sections Megalocystis and Theiochrus.

Species containing nitro compounds that are catabolized to 3-NPA in ruminants range from highly poisonous to virtually harmless. In general, species with a leaf content of $20 \mathrm{mg} \mathrm{NO} / \mathrm{g}$ or higher (dry wt) as 3-NPA would be classified as poisonous and unsuitable for release. These could cause both acute and chronic poisoning in livestock. Most 3-NPA species in this category are noted for wide fluctuations in nitro content that may reach 60 to 80 $\mathrm{mg} \mathrm{NO} / \mathrm{g}$ in leaves during vegetative-to-bloom stage of growth. This group included all species so far examined in section Uliginosi and Astragalus macropterus DC. of section Hemiphaca. As natural components of ranges and pastures in the western United States, the indigenous 3-NPA Astragalus have not been recognized as a livestock-poisoning problem. One possible exception is $A$. canadensis which has reportedly caused cattle losses in Oregon. Chronic and acute poisoning have been produced experimentally in ruminants with both $A$. canadensis and sicklepod milkvetch
Williams and James 1978; Williams et al. 1976).

Astragalus species that synthesize 10 to $19 \mathrm{mg} \mathrm{NO} / \mathrm{g}$ as 3-NPA would be moderately toxic; but under range conditions, acute poisoning would rarely occur. Chronic poisoning could occur if the plants were heavily grazed during vegetative growth when 3-NPA content was highest.

Species that synthesize less than $10 \mathrm{mg} \mathrm{NO} / \mathrm{g}$ as 3-NPA are marginally toxic. Toxicity is apparent with the chick bioassay but only in doses of 6 to $9 \%$ of body weight. Seeding these species so that they comprised a major part of the available forage might produce chronic poisoning. Extended feeding studies with cattle and sheep should be conducted with Astragalus species that synthesize 3-NPA at 5 to $15 \mathrm{mg} \mathrm{NO} / \mathrm{g}$ to determine if pathological changes occur. The analyses reported here are based on a small sample of individual species, many grown under greenhouse conditions, which may not correspond to nitro analyses under range conditions.

More than $50 \%$ of the North American Astragalus accessions previously examined synthesized nitro compounds (Williams and Barneby 1977a). Based on the foreign introductions studied, nitro synthesizing species would not be expected to exceed 30 to $35 \%$ of future introductions, while 65 to $70 \%$ of the 1,400 to 1,500 known foreign Astragalus species would be free of harmful compounds. Besides nitro compounds, some Astragalus species accumulate selenium to toxic levels. Davis (1972) found toxic levels of selenium in 25 of 48 introduced Astragalus species grown in soils containing $18 \mathrm{ppm}$ selenium. Such species could be hazardous to livestock if they were seeded on seleniferous soils in the western United States. A recommended screening process for new Astragalus introductions should include (1) analysis for the presence and type of nitro compound; (2) a study on selenium accumulation; and (3) toxicological studies with laboratory and domestic animals to insure that no other toxic compounds are present. The Astragalus that were shown to be free from toxic components would provide an adequate reservoir of species from which useful cultivars could be developed without releasing potentially harmful species.

\section{Literature Cited}

Anonymous. 1977. Register of Australian herbage plant cultivars. B. Legumes. 18. Astragalus. J. Aust. Inst. Agr. Sci. 43:90-92.

Cooke, A.R. 1955. The toxic constituent in Indigofera endecaphylla. Arch. Biochem. Biophys. 55:114-120.

Davis, A.M. 1972. Selenium accumulation in Astragalus species. Agron. J. 64:751-754.

Desborough, P.J. 1976. Evaluation of cool-season, annual legume species on alkaline, cracking-clay soils at Narrabri, New South Wales. I. Initial survey. Aust. Plant Intro. Rev. 11:2-16.

Majak, W., and R.J. Bose. 1974. Chromatographic methods for the isolation of miserotoxin and detection of aliphatic nitro compounds. Phytochemistry 13:1005-1010.

Williams, M.C. 1980 . Purposefully introduced plants that have become noxious or poisonous weeds. Weed Sci. 28:300-305.

Williams, M.C. 1980. Toxicological investigations on Astragalus hamosus and Astragalus sesameus. Aust. J. Exp. Agr. Anim. Husb. 20:162-165.

Williams, M.C., and R.C. Barneby. 1977a. The occurrence of nitro-toxins in North American Astragalus (Fabaceae). Brittonia 29:310-326.

Williams, M.C, and R.C. Barneby. 1977b. The occurrence of nitro-toxins in Old World and South American Astragalus (Fabaceae). Brittonia 29:327-331.

Williams, M.C., and L.F. James. 1975. Toxicity of nitro-containing Astragalus to sheep and chicks. J. Range Manage. 28:260-263.

Williams, M.C., and L.F. James. 1978. Livestock poisoning from nitrobearing Astragalus. In: Effects of Poisonous Plants on Livestock, R.F. Keeler, K.R. Van Kampen, and L.F. James, eds. Academic Press, New York, p. 379-389.

Williams, M.C., L.F. James, and A.T. Bleak. 1976. Toxicity of introduced nitro-containing Astragalus to sheep, cattle, and chicks. J. Range Manage. 29:30-33.

Williams, M.C., L.F. James, and B.o. Bond. 1979. Emory milkvetch (Astragalus emoryanus var. emoryanus) poisoning in chicks, sheep, and cattle. Amer. J. Vet. Res. 40:403-406.

Williams, M.C., and F.A. Norris. 1969. Distribution of miserotoxin in varieties of Astragalus miser Dougl. ex Hook. Weed Sci. 17:236-238. 